\title{
Size- and Shape-Dependent Clinical and Mycological Efficacy of Silver Nanoparticles on Dandruff [Corrigendum]
}

Anwar M, Yadav D, Jain S, et al. Int J Nanomedicine. 2016;11:147-161.

The authors have advised due to an error at the time of figure assembly, Figure 4A on page 156 is incorrect. The correct Figure 4 is shown below.
The authors apologize for this error and advise it does not affect the results of the paper.
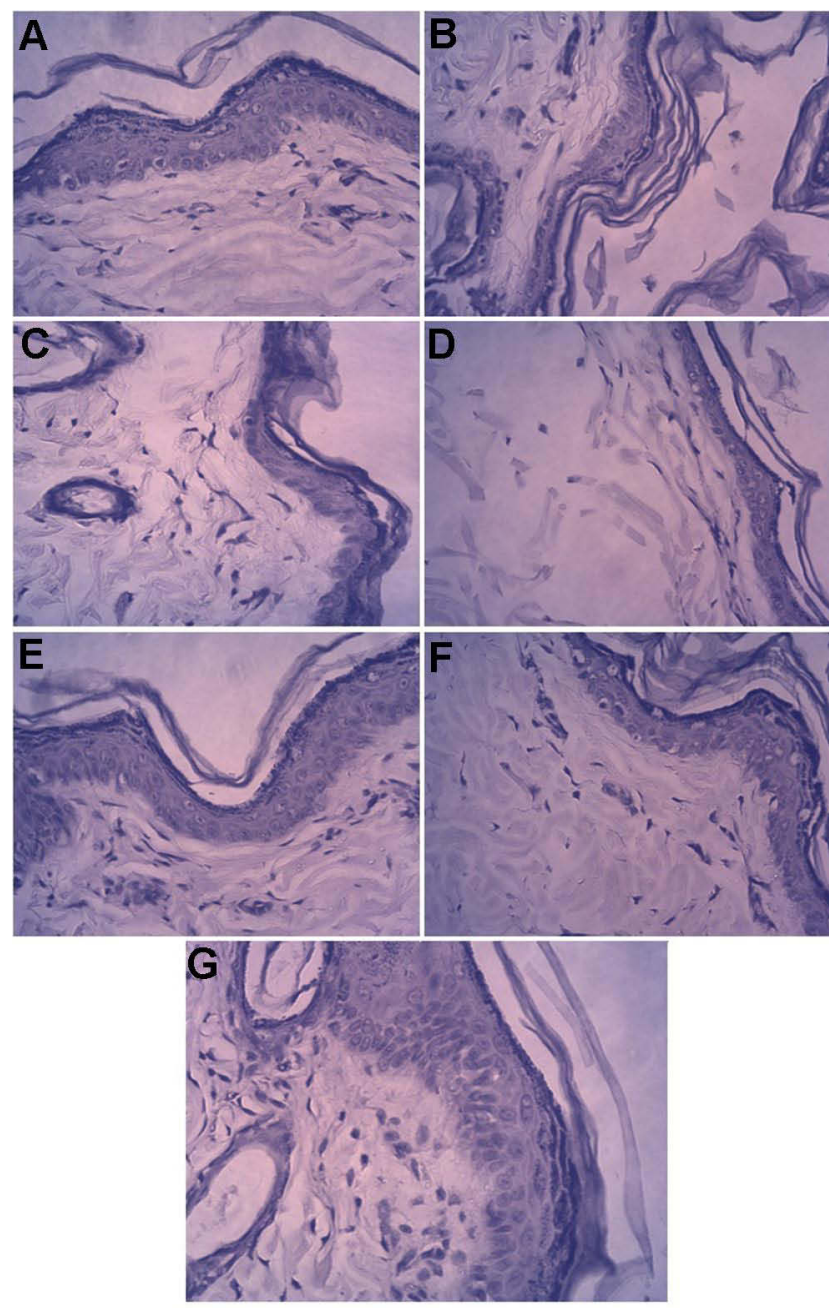

Figure 4 Histopathological microphotographs of different groups of studied rats.

Notes: (A) Control I; (B) M. furfur diseased model group II; antifungal agent-treated groups; (C) III (itracanozole); (D) IV (ketoconazole); (E) V (20 nm spherical-shaped Ag $\mathrm{NPs}) ;(\mathbf{F}) \mathrm{VI}(50 \mathrm{~nm}$ spherical), and (G) VII (50 nm rod-shaped Ag NPs).

Abbreviations: M. furfur, Malassezia furfur; NPs, nanoparticles. 


\section{Publish your work in this journal}

The International Journal of Nanomedicine is an international, peerreviewed journal focusing on the application of nanotechnology in diagnostics, therapeutics, and drug delivery systems throughout the biomedical field. This journal is indexed on PubMed Central, MedLine, CAS, SciSearch ${ }^{\circledR}$, Current Contents ${ }^{\mathbb{B}} /$ Clinical Medicine, $^{2}$
Journal Citation Reports/Science Edition, EMBase, Scopus and the Elsevier Bibliographic databases. The manuscript management system is completely online and includes a very quick and fair peer-review system, which is all easy to use. Visit http://www.dovepress.com/ testimonials.php to read real quotes from published authors.

Submit your manuscript here: https://www.dovepress.com/international-journal-of-nanomedicine-journal 